\title{
THE IMPLEMENTATION OF RESTORATIVE JUSTICE AT THE WOMEN AND CHILDREN PROTECTION UNIT OF BENGKULU POLICE RESORT (CASE STUDY ON SEXUAL CRIME)
}

By:

Aziza Yuli Susanti, Antory Royan A, Lidia Br Karo

\begin{abstract}
The frequent occurrence of cases of which the solutions did not prioritize the best interest for all parties which commonly called as Win-Win Solution resulted in Criminal Justice System to implement Restorative Justice System Justice in which considered to be better because it fix the relation between the victim and the perpetrator. This thesis research used empirical legal research method, the data used was primary, secondary, and tertiary data. The population in this study was all the investigators and co-investigators of Women and Children Protection Unit as well as all the parties who have dealt with Women and Children Protection Unit of Bengkulu Police Resort. Data analysis performed through descriptive qualitative method which elaborates the data in the form of sentences systematically based on the statements obtained from the result of the study in the field. The result of this study was in order to manifest an ideal role, investigators need to undergo development and improvement in various aspects, among others are: it is necessary to do socialization and coordination, improvement of quality as well quantity of adequate human resources, in order to be skillful, tenacious, and responsible and professional.
\end{abstract}

Keywords: Implementation of restorative justice, Women and Children Protection 


\section{A. INTRODUCTION}

\section{Background of the Study}

Crime of criminal act is one form of "deviant behavior" which always exists and is inherent in every society, there is no society which is desolate from crime. According to SaparinahSadli as cited by Muladi states that deviant behavior is social norms which become the basis of life or social order, it can cause individual tension as well as social tensions and is real threat or has potential for the ongoing social order. ${ }^{1}$

Where there is a society there is a crime, this statement has a meaning that where there is a development or a growth of society then crime will also develop, one of the ways to prevent this condition is by doing prevention, control as well as countermeasure of crime by using law facility. "Law is a regulation made and agreed both written and unwritten;

${ }^{1}$ Muladi and BardaNawawiArief, Teori-TeoridanKebijakanPidana, Alumni, Bandung, 2010 p.148 regulation, a law which bonds behavior of each particular society." 2

As explained by L. Pospisil cited by Lili Rasjidi explains about law, las functions as a social control facility. To distinguish between law and other norms, it is known four characteristics of law or attributes of law as follow:

1. The main attribute is called as attributes of authority, in which law is decisions of authority of which the purpose is to overcome all the oppositions and shocks occurred in a society.

2. The second attributes is known as attributes of intention of universal application, in which decisions have long reachability for the future time.

3. The third attribute is called attributes of

\begin{tabular}{|c|c|}
\hline${ }^{2}$ Daryanto, & Kamus \\
\hline $\begin{array}{l}\text { Indonesia Lengkap, } \\
\text { Surabava 1997.p.271 }\end{array}$ & Apollo \\
\hline
\end{tabular}


obligation in which the decisions of authority should contain obligations of the first part toward the second party or vice versa. If they do not contain such matter then those decisions are not legal decisions.

4. The fourth attribute is attributes of sanction in which the decisions of authority should be supported by sanction, both physical and spiritual sanctions. $^{3}$

In law enforcement it is known a term of integrated criminal justice system which is an integrated criminal justice system regulated in Criminal Procedure Code, this integrated system is put on top of basic principle of "functional differentiation" among law enforcement apparatus based on "authorized process step" which

${ }^{3}$ Lili Rasjidi, FilsafatHukum, ApakahHukumItu?, RemajaRosdakarya Co., Bandung, 1991, p.36 is given law to each of them, consisted of:

- Investigator

- Public Prosecutor

- Judge, and

- Correctional Institution Apparatus

As for the main goals of "combined function" in the framework of criminal justice system are to enforce, to implement and to run criminal law. ${ }^{4}$

Restorative Justice is followed up by the Lettergram of KapoldaBenngkulu number : ST/27/VIII/2012 dated on 1308-2012 on the implementation of Restorative Justice at Polda Bengkulu $^{5}$ as well as the existence of Memorandum of Understanding between the Chief of Supreme Court, Minister of Law and Human

\footnotetext{
${ }^{4}$ YahyaHarahap,

PembahasanPermasalahandanPenerapan KUHAP, PenyidikandanPenuntutan, SinarGarfika, Jakarta, 2004, p.90

${ }^{5}$ TR from Kapolda Bengkulu number: ST/27/VIII/2012 dated on 12-082012 on the implementation of Restorative Justice at Polda Bengkulu
} 
Rights, General Attorney and Head of Indonesian National Police dated on $17^{\text {th }}$ of October $2012^{6}$ who made agreement including criminal case which included as minor category can be resolved through Restorative Justice.

This condition brings fresh air for criminal justice, as it is explained that with the existence of Restorative Justice both disputing parties can do mediation accompanied by law enforcer where in this case is Police, therefore minor criminal case can be solved without passing through criminal path.

By applying restorative justice method, the expected result is the decrease in the number of children being arrested, imprisoned, and sentenced to jail; eliminate the stigma and restore the children to be normal human thus

${ }^{6}$ Memorandum of Understanding between the Head of Supreme Court, Minister of Law and Human Rights, General Attorney and Head of Indonesian National Police dated on $17^{\text {th }}$ of October 2012 in Jakarta expected to be useful in the future time; children criminal subjects can realize their faults so that they would not repeat their actions; decrease the workload of police, prosecutor, jail, court and correctional institution; save states finance, does not cause resentment because the perpetrator has been forgiven by the victim; victims quickly get compensation; empower parents and the community in overcoming child delinquency and reintegrating children into society. $^{7}$

In the peace process, the perpetrator's family and the families of the victims are required to be present and witnessed by local government officials such as the RT / RW and the Customary Consultative Body or the Office of Community Empowerment, Women and Child Protection,

\begin{tabular}{lrr}
\hline${ }^{7}$ Rika & Saraswati, & 2009, \\
HukumPerlindunganAnak di & Indonesia, \\
Citra Aditya Bakti Co., Bandung, Pp & $135-$ \\
136 &
\end{tabular}


Population Control and the Bengkulu City Family Planning as well as Social Officers.The implementation of restorative justice in the process of handling optimizes the involvement of other stakeholders such as local government starting from RT / RW of Subdictrict and involvement from local Customs considering the enactment of Local Regulation on Customs, Bengkulu City Regional Regulation No. 29 of 2003 which in this regulation also regulated the settlement of minor cases by means of deliberation and consensus. ${ }^{8}$

Restorative Justice is more emphasized in criminal cases involving children, as children is the mandate of God Almighty that must be protected, because their nature is still vulnerable and dependent on adults. Children also become the next generation. But in reality, various cases of child abuse that

${ }^{8}$ Local Regulation of Bengkulu City No. 29 of 2003 on the Implementation of Bengkulu City Customs have emerged lately are very worrying. So many children are victims of violence both within the family, the environment and the community. ${ }^{9}$

According to Law No. 35 of $2014 \quad$ concerning Amendments to the Republic of Indonesia Law No. 23 of 2002 concerning Child Protection Article 1 item 15 a, namely violence against children is any changes to children which results in suffering in psychological, sexual, and / or neglect, , including threats to commit acts, coercion or deprivation of liberty against the law.

Sexual crimes are faced by many children. Sexual violence against children can occur in various forms in various conditions and situations, against boys and girls. The form can be

${ }^{9}$ Ministry of Communication and Information of Republic of Indonesia General Directorate of Information and Public Communication, Directorate of Management and Information Providing, 2015, AkuAdalahAnugrah Stop KekerasanTerhadapAnak, Kominfo, p.13 
in the form of sexual harassment, sexual intercourse with children, and sexual exploitation. The culprit is not only an unknown person, but can be known to a child, a person trusted by a child, or even a family relative of a child.

Cases of sexual violence against children and women, such as sexual intercourse with children, always stop at the point of victim's reluctance to report to law enforcement officials because of feeling embarrassed and not opening up shame to others, or feeling threatened by the perpetrator, trauma, shock, depression. And even if there are cases that have been successfully processed to court, many of them do not provide results that are in accordance with the expectations of victims, perpetrators of sexual intercourse with children are not subject to a maximum penalty in accordance with the provisions of the Children Protection Law.

Based on the data above, it can be seen in the case of sexual crimes, the implementation of Restorative Justice which after the peace agreement was reached was suggested to those who reported to revoke the complaint report and carried out the termination of the investigation after being held the internal criminal case with the internal police supervision function (supervision section) involving local government tools such as RT / RW and Customary Consultative Body, Social Officers.

The process of implementing Restorative Justice, after the examination / investigation process is completed, the child with problems with the law is not detained, through the SP 3 mechanism (termination of the investigation). After peace has been agreed between the victim and the perpetrator, if the agreement is violated by the perpetrator then the victim's parents cannot continue the report because SP3 has been 


issued (termination of the
investigation) by the
investigator. Based on the
background above, the writer
considers it very important to
raise the issue in academic
studies through thesis research,
entitled "THE
IMPLEMENTATION OF
RESTORATIVE JUSTICE AT
THE WOMEN AND
CHILDREN PROTECTION
UNIT OF BENGKULU
POLICE RESORT (CASE
STUDY ON SEXUAL
CRIME)"

2. Identification of the Problem

Based on the background above, then the problem discussed by the writer was:

1. What were the efforts of the Investigator at Women and Children Protection Unit to make the implementation of Restorative Justice became effective?

\section{B. RESEARCH METHODS}

Method or type of research used in this study was
Empirical Legal Research, according to SoerjonoSoekanto empirical research method studies secondary data for then continued by study on primary data on the field or toward society, in which used data source and research pattern of social sciences and stressed more on the observation aspect. $^{10}$

Empirical

Legal Research is directed toward identification (introduction) on the applicable real law, which applicable implicitly (entirely) not explicitly (clear, firm, ruled) in the regulation or elaborated in the library, so that the study on the Implementation of Restorative Justice Method in Children Justice System at the Women and Children Protection Unit of Bengkulu Police Resort can be answered.

Location or place of study is the place where the study process is performed to obtain solution to the ongoing

\footnotetext{
${ }^{10}$ Ibid p.52
} 
research problem ${ }^{11}$, the research location in this study was centered at the Women and Children Protection Unit of Bengkulu Police Resort which aimed to identify the Implementation of Restorative Justice Method in the Children Justice System.

\section{RESEARCH RESULTS AND DISCUSSION}

Indonesian National

Police is one law enforcement institution which has main duties to protect and to provide service to the society as well as to maintain security of social order as amended in Law No. 35 of 2014 on the amendment of Law No. 23 of 2002 on Children Protection.

Currently, the Head of Indonesian National Police, Police General Tito Karnavian has "Promoter" program which represents Professional, Modern and Trusted. As for the

\footnotetext{
${ }^{11}$ Sukardi, 2009 , MetodologiPenelitianPendidikanKompetensi danPraktiknya, BumiAksara, Jakarta, p.53
}

elaboration of "Promoter" is as follow:

- Professional: Improving the competence of human resources of Indonesian National Police which more qualified through the improvement of education capacity and training, as well as conducting policing patterns based the standard procedure which has been understood, implemented, and can be measured in term of success.

- Modern: conducting modernization in public service supported by technology so that it becomes easier and faster to be accessed by society, including the fulfilment of more modern Almatsus and Alpakam necessities.

- Trusted: conducting internal reformation for Indonesian National Police which is clean and 
free from corruption, for the manifestation of law enforcement which is objective, transparent, accountable, and justified.

Ideally, the law which is expected to be able to direct and to accommodate legal necessities in accordance to legal awareness of society that develop toward modernization to guarantee legal certainty of social order, in other words law should be able to adapt to the speed of change and the demand of society as well as should be able to be used as facility for giving direction for the changes.

The following as the steps of Women and Children Protection Unit of Bengkulu Police Resort to manifest an ideal role for Investigator of sexual criminal act, which are by:

a. Keeping the victim's identity secret, the aim is that victims of sexual intercourse, sexual abuse and other cases do not experience the second time of abuse, namely harassment committed by the community.

b. Providing counseling outside the legal path, with this counseling, it is expected that the victims can tell in truth and as clearly as possible the events they experienced without fear and stress. That way the police are also easy to conduct investigations.

c. Conducting investigation attempts

- Accepting report

- Conducting

Visum et Repertum

- Gathering witnesses

- Handling the subject of criminal act of sexual intercourse, sexual abuse and other cases 
d. GivingLetter of

Notification of

Investigation Results

Progress with the aim

that both the victim and

the family feel taken care

of by the police.

e. Conducting coordination

with women and children

protection institution and

other Non-governmental

organizations which

protect women and

children.

f. Conducting socialization and coordination together with criminal justice system element such as coaching, seminar or internal training or in cooperation with related institution.

g. Improving quality and quantity of human resources which is adequate, skillful, tenacious and responsible so that they are able to do a certain job rationally. One of the ways is by performing psychology test periodically to find out the mental state of the personnel as human resources which is in charge in the field of Criminal Investigation.

h. Improving professionalism in the form of personnel's competence by performing knowledge improvement, ability improvement and appetency improvement of the personnel, among others are:

- Fulfilment of human resources requirement particularly for certified instructor and has qualification on the field of Criminal Investigation.

- Forming unit/team consisted of combined personnel which are trained and have the knowledge of Criminal Investigation. 
- Providing knowledge on culture and good behavior and good communication

method with the society;

- Providing education and learning as well as understanding comprehensively related to the ethics of good Investigator and Co-investigator in accordance with society's expectation;

- Providing education and training on technology mastery which support the realization of technology-based professionalism of Indonesian National Police so that there will be manifestation of efficiency, effectiveness as well as broadminded.

- Giving reward and punishment as motivation to the personnel.

- Improving the quality of human resources in spiritual field.

- Providing understanding of the importance of investigation process of criminal act which should be objective, professional, proportional and without pressure from any party.

HadiSupeno states that there are three main aspects in restorative justice, which are:

1. Restoration

In this case, the process carried out is not about gaining a victory or accepting defeat, accusation, or revenge, but about justice for all parties involved.

2. Relationship recovery

It is not punishable, whereby the perpetrator of a crime must assume responsibility for the crime committed and correct it in a 
number of ways, but through a process of open and direct communication between the victim and the perpetrator of the crime which in the end has the potential to change the way of the disturbed relationship to be good again.

3. Reintegration

On a broader level, restorative justice provides a place for children and parents and other parties involved to obtain a fair process. The point is that all parties involved can learn about the consequences of the crimes that occur and understand the impact of these actions on others. $^{12}$

Based on the interview with Ermawati as the Head Section of PUG Gender Mainstreaming of Community Empowerment Services, Women and Child Protection, Population Control and the Bengkulu City

\footnotetext{
${ }^{12}$ HadiSupeno 2010, p.203, KriminalisasiAnakTawaranGagasanRadikal PeradilanAnakTanpaPemidanaan, GramediaPustakaUtama Co., Jakarta.
}

Family Planning on $12^{\text {th }}$ of May 2017 explained that in realizing an ideal role in the case of women and children which is by suggesting the investigator together with Criminal Justice System element as well as related institution such as Social Department and other NonGovernmental Organizations needs to do socialization and coordination like coaching, seminar or training internally or in cooperation with related institution in order for the Law No. 11 Year 2012 on Children Criminal Justice System can be used maximally and effectively.

\section{CLOSING}

\section{Conclusions}

1) The efforts conducted by investigator in realizing an ideal role in the implementation of Restorative Justice in Children Justice System at the Women and Children Protectio Unit of Bengkulu Police Resort are: 
- It is necessary to do socialization and coordination

coherently with criminal justice system element such as coaching, seminar or training internally or in cooperation with related institutions;

- It is necessary to improve the quality and quantity of human resources which are adequate, skillful, tenacious and responsible;

- The needs for the improvement of professionalism in the form of personnel's competence by performing knowledge improvement, improving ability and improving personnel's appetence.

\section{Suggestions}

From the conclusions above, the writer proposed several suggestions for the consideration in the future time:

1. It is necessary to held legal socialization activity toward the society about Law Number 35 of 2014 on the amendment of Law of Republic of Indonesia No. 23 of 2002 on Children Protection conducted by police or other law enforcers as well as other institutions on the importance of religion, family, to be able to respect each other, remind each other, and also control so that the children continue to uphold the dignity, which the children bring the good name of their family.

2. Due to the complexity of the problem faced by the officers of Women and Children Protection Unit in 
handling the victim, it would be better to provide education or specific school in order for the officers of Women and Children Protection Unit to be more professional and good in doing their noble duty.

\section{REEFERENCES}

A. Books

$$
\begin{array}{cc}
\text { Daryanto, Kamus } & \text { Bahasa } \\
\text { Indonesia } & \text { Lengkap, } \\
\text { Apollo } & \text { Lestari, } \\
\text { Surabaya, } 1997
\end{array}
$$

Hadi Supeno, 2010, hlm 203, Kriminalisasi Anak Tawaran Gagasan Radikal Peradilan Anak Tanpa Pemidanaan. PT. Gramedia Pustaka Utama, Jakarta.

Kementerian Komunikasi dan Informatika Republik Indonesia Direktorat jenderal Informasi dan Komunikasi Publik Direktorat Pengolahan dan Penyediaan Informasi, 2015, Aku Adalah Anugrah Stop Kekerasan Terhadap Anak, Kominfo
Lili Rasjidi, Filsafat Hukum, Apakah Hukum Itu ?, PT. Remaja Rosdakarya, Bandung, 1991

Muladi dan Barda Nawawi Arief, Teori-Teori dan Kebijakan Pidana , Alumni, Bandung, 2010

Rika Saraswati, 2009, Hukum Perlindungan Anak di Indonesia, PT Citra Aditya Bakti, Bandung

Sukardi, 2009, Metodologi Penelitian Pendidikan Kompetensi dan Praktiknya, Bumi Aksara, Jakarta

Yahya Harahap, Pembahasan Permasalahan dan Penerapan KUHAP, Penyidikan dan Penuntutan,Sinar Grafika, Jakarta, 2004

B. Regulation

Kitab Undang-Undang Hukum Pidana

Kitab Undang-Undang Hukum Acara Pidana

Undang-Undang Nomor 11 Tahun 2012 tentang Sistem Peradilan Pidana Anak

TR dari Kapolda Bengkulu nomor : ST / 27 / VIII / 2012 tanggal 13-082012 tentang penerapan Restorative Justice di Polda Bengkulu 
Nota Kesepakatan Bersama antara Ketua MA, Menteri Hukum dan HAM, Jaksa Agung dan Kapolri tanggal 17 Oktober 2012 di Jakarta

Perda Kota Bengkulu No:29 Tahun 2003 tentang Pemberlakuan Adat kota Bengkulu. 